\title{
The Investigation And Analysis On The Life-span Of Residential Buildings
}

\author{
Haoran $\operatorname{Ran}^{1, a}$ \\ ${ }^{1}$ School of Xi'an University of Architecture And Technology, Xi'an 710055, China \\ a449018071@qq.com
}

\begin{abstract}
Keyword: Residential buildings Life-span; Sampling survey ; Questionnaire survey; Sustainable development
\end{abstract}

\begin{abstract}
Gan Da Lei" house building strategy which is aimed to meet the basic need during that material-lacking period in 1960s, for the booming development of concrete jungles of commercial residential buildings that comes with the reform and opening-up policy, the form of China's residential buildings has been changing with the development of social economy, enterprise unit courtyard, for example, is a living proof of this dramatic change. In this paper, 143 removed and soon-to-be-removed traditional enterprise unit buildings in Lintong, Xi'an, are used as investigation subject. Residents here are inquired with questionnaires,in ordered to figure out the residential buildings' life-span and people's understanding about it. Mathematical and statistical methods are used to get more accurate result and analysis so as to lay the basis for buildings' remolding and sustainable development.
\end{abstract}

\section{General Introductions}

China's urbanization strategy will change suburbs buildings, and urban village which holds about 100 million people into modern city buildings. In the meantime, huge consumption of manpower, material resources, financial resources and energy are caused by these processes. We have been seeing heaps of construction wastes polluting soil and water when burned or buried. These series of problems go absolutely against sustainable development. Urban residential buildings are the major part of the city constructions and they consume large amount of resources. Furthur, life-span of urban residential buildings is not only a part of the rational distribution of constructional and financial resources, but also a part of issues such as healthy social production, environmental conditions and urban sustainable development. A filed investigation on this subject can provide our government's scientific control and related institution's management with statistical basis, as well as certain enterprises' strategic tools when investing in residential buildings.

Our country's residential buildings have always been changed with government's economic strategy, from the "Gan Da Lei" house building strategy which is aimed to meet the basic need during that material-lacking phase in 1960s, to the booming development of concrete jungles of high commercial residential buildings that comes with the reform and opening-up policy. There is no doubt that today's new residential building form will take the previous one's place. Many buildings are being pulled down and then new ones are standing up. This brings out another focus of our research, namely what is the proper life-span of a building on the premise of the fulfillment of its use function and economic function

Scholars at home and abroad have done studies about constructions' life-span. Canadian scholars o 'connor(2004) investigated 227 dismantled buildings in the north American cities and it is concluded that the catagory of structure is not the main factor affecting its life-span [1].Taiwanese scholar You sheng Zhang(2002) researched on millions of buildings in Taiwan's four largest cities, then come up with a conclusion that the residential buildings' life-span in Taiwan is 35 to 40 years [2]. Japanese scholars(2004) investigated and studied the factors affecting the life-span of buildings in east and south Asia, and pointed out that the ageing factor accounted for $47 \%$, function-improving factor 7\%, other economic and social factors $50 \%$ [3]. Based on the field investigation of 3255 buildings removed in Chongqing, given some analyses of the factors 
affecting life-span of the building due to its own factor, Liu guiwen also found some ways to extend the life-span of the buildings [4]. Zhang mengli analyzed the effecting factors using Logistic mold and found out the reasons that caused our country's buildings' short life-span [5]. Xu ke xi chose the point of location and come up with the idea that non-fetself-factor also has affection on buildings' life-span [6]. Ou yang jian tao figured out the average life-span of China's residential buildings through mathematical ways [7].Chen jian jun took the designing point of view and discussed on this subject, he also proposed some ideas about how to prolong the short residential buildings' life-span [8]. Chen jian analyzed on the external factors and pointed out that things like the city plan, social economy, and laws also effected the life-span of buildings [9].

This research is to build up a new horizon and concept among the city's governors, building designers, residents and managers.Through some simple statistics of life-span of removed and soon-to-be-removed buildings, and people's understanding of environment friendly buildings, we would like to see that it is helpful in urban residential buildings' sustainable development.

\section{Research Methods}

Firstly, 200 copies of questionnaires were handed out in residential district located in Lin tong,Xi'an. Filtering and analyzing all the information in these questionnaires,we an can catch a comprehensive glimpse of people's understanding about residential buildings' life-span and this may serve as some practicable advice on residential building reform in the future.

Secondly, a sampling research has been done on the residential buildings in Lin tong, Xi'an. Statistics from this sampling research have been processed and analyzed by mathematical and statistical methods in an effort to work out average life-span of residential buildings, and correlation analysis has been made.

\section{Conclusion of Questionnaire}

1) According to the questionnaires, we came to a conclusion that the existing buildings are built mainly in late 1980s and early 1990s during which the majority of buildings are 5 to 7 stories high. As real estate and residential buildings became commercialized, and a boost in residential buildings has come in sight since late 1990s, residential community appeared in larger scale. In the latter half of $1990 \mathrm{~s}$, number of residential buildings has been increasing sharply and it takes up over $80 \%$ of all. So we can say that the existing buildings are mostly 20 years old with a per area of $70 \mathrm{~m} 2-$ $140 \mathrm{~m} 2$.

2) Most people know little about energy-saving buildings in Lin tong. Over half of the interviewees are not aware of the existence of energy-saving buildings in their area. $39 \%$ of them have no idea about energy-saving buildings and $60 \%$ only heard about it without experiencing it. Only $9 \%$ of them know exactly how they work and function. Therefore, we should take more effort to promote the concept of energy-saving buildings so as to push the pace of sustainable development of energy-saving in residential buildings forward. It is recognized by most people that energy-saving does have some effect on the residential buildings' life-span, work the same the other way around. So this leaves us a new method and new way to extend buildings' life-span.

3) The questionnaires are about factors that effect the life-span of residential buildings, the result shows that people think city plan, government decision, construction design, and conducting quality are the major factors. If we want a building to last over 100 years, we must have a long-term perspective and a comprehensive city plan to complete our laws and regulations and to take into account the function and aesthetics of buildings. Needless to say, conducting quality is also a major issue hereby to avoid poor-quality structure.

4) As for how to extend life-span of residential buildings, we are aware of the lack of promotion made by our government, which exposes the problem that the concept of residential buildings' life-span has not been seen as important as it should have been by both developers and residents.

5) Finally, about people's cognition about the effect of saving energy on society, we can see people's expectations are rather high. But due to immaturity of energy-saving technology, limited 
research on buildings' life-span and incomplete theory reserve, our government should promote people's knowledge about energy-saving buildings and enhance the practice of conducting, eventually to merge idea with practice.

\section{The Collection and Analysis of Residential Life in Lin tong}

\subsection{Analysis of the Overall sample life}

Based on the analysis of 143 samples, the samples were removed and demolition of buildings is the life of the arithmetic mean is 31.09 , the median is 28.00 , the number 26 , the standard deviation was 10.487 , a 0.647 of skew ness and kurtosis of 0.128 . Considering the characteristic values of samples showed normal distribution (figure 1). This research adopts the arithmetic average on behalf of the statistical samples removed and the arithmetic average will be 31 years.

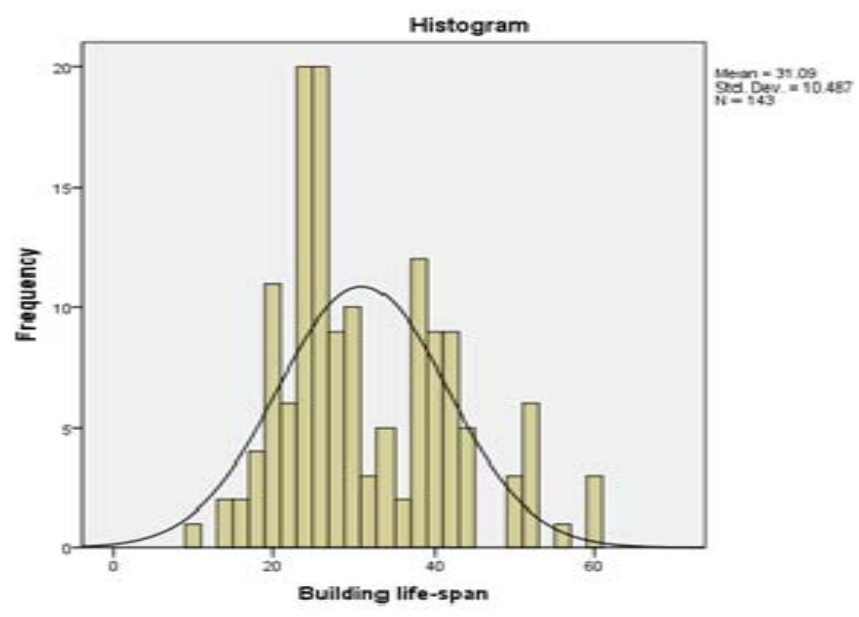

Figure 1. diagram of buildings' life-span

\subsection{Feature of ResidentialBbuildings' Life-span}

1) Classified by building time: from figure 1, buildings built in 1980s take up the biggest portion $81.1 \%$ in removed buildings and $2.1 \%$ in the 1990 s, which matches the development history during the past 30 years.

Early days of new China, we stared out by massively building all kinds of buildings and public structures. Unfortunately, because of the low level economic development, backward building technology, and the old-fashioned values and policy, buildings built during this period turned out to be low in standard and poor in quality. And these buildings become the main project of today's reform of old and dilapidated buildings. After 1990s, the newly built residential buildings have improved in quality standard, supporting facility and surrounding environment thanks to the improvement of technology and better city plan, whivh contributes to the lower rate of buildings' being removed.

Table 1. Residential Buildings' Built Time

\begin{tabular}{|c|c|c|c|c|c|}
\hline \multicolumn{6}{|c|}{ Time for completion } \\
\hline & & \multicolumn{2}{|c|}{\begin{tabular}{|c|c} 
Freque & percentag \\
ncy & $\mathrm{e}$
\end{tabular}} & $\begin{array}{l}\text { Effective } \\
\text { percentage }\end{array}$ & $\begin{array}{l}\text { Cumulative } \\
\text { percentage }\end{array}$ \\
\hline \multirow{6}{*}{$\begin{array}{l}\text { Effec } \\
\text { tive }\end{array}$} & $1950 \mathrm{~s}$ & 6 & 4.2 & 4.2 & 2.1 \\
\hline & $1960 \mathrm{~s}$ & 28 & 19.6 & 19.6 & 23.8 \\
\hline & $1970 \mathrm{~s}$ & 73 & 51.1 & 51.1 & 74.8 \\
\hline & $1980 \mathrm{~s}$ & 33 & 23.1 & 23.1 & 81.1 \\
\hline & $1990 \mathrm{~s}$ & 3 & 2.1 & 2.1 & 100.0 \\
\hline & Total & 143 & 100.0 & 100.0 & \\
\hline
\end{tabular}

2) Classified by building structure: the result shows that frame structure buildings last the longest for about 59 years, reinforced concrete structure buildings last the shortest for about 12 
years. Frame structure buildings' relatively complete skeleton makes them easier to rebuild. Northwest chemical research institute, one of our researched buildings, a three-story bachelor apartment, is a building rebuilt from old classroom building. Its basic structure makes it easy for partition and retouch. Concluding from the survey, a building's life-span doesn't have positive correlationship with its structure.

\subsection{Factors affecting the life-span of residential buildings}

Factors affecting the life-span of residential buildings Internal factors: buildings' structure, story of building. External factors: city plan, government decision, land value. In this research we focused more on analyzing the external factors (Table 2).

Table 2 Correlationship Between Buildings' Life-span and External Factors

\begin{tabular}{|c|c|c|c|}
\hline \multicolumn{4}{|c|}{ Correlation } \\
\hline & & $\begin{array}{l}\text { Building } \\
\text { structure }\end{array}$ & $\begin{array}{l}\text { Building } \\
\text { layers }\end{array}$ \\
\hline \multirow{3}{*}{$\begin{array}{l}\text { Building } \\
\text { structure }\end{array}$} & Pearson Correlation & -.200 & -.216 \\
\hline & Sig.(2-tailed) & & .000 \\
\hline & $\mathrm{N}$ & .000 & -.169452 .3 \\
\hline \multirow{3}{*}{$\begin{array}{l}\text { Building } \\
\text { layers }\end{array}$} & Pearson Correlation & $-.2572,287$ & -7.389 \\
\hline & Sig.(2-tailed) & -4.754 & \\
\hline & $\mathrm{N}$ & 2271 & 2271 \\
\hline
\end{tabular}

1) A building's structure type shows no obvious correllationship with its life-span: from correlationship angle, under the level of 0.01 , a building's life span has a negative correlationship with its structure. This means the longer the designing life-span, the shorter the building's real life-span. So, structure of residential buildings is not a main factor of their life-span, there's no obvious correlationship between them.

2) The story of a building is not the main factor of its life-span: a building's life-span and its number of story is negatively correlated under the level of 0.01 , which means number of a building's story is not a main factor of its life-span. Because most of buildings studied in our research are enterprises' self-built residential buildings, companies often have the whole control of the property right, this makes enterprises' self-built residential buildings easier to removed than private buildings. Managers of those companies builded their staffs' residential buildings based on their companies' benefit and interest. A company in good shape would probably remove residential buildings that are not decent enough or not convenient for the daily life of staff, and would build a better one on the exact same spot to contribute to the short life-span of enterprises' residential buildings.

\section{Conclusion and suggestion}

Conclusion: In order to do this research, questionnaires about people's understanding of residential buildings' life-span and energy-saving residential buildings were given out. Meanwhile, taking Lin tong district as an example, and Li shan street and Shan gu avenue as two samples, with 143 removed and to-be removed buildings being studied for statistics, we have rounded up to the following conclusions.

1.Common residents acquire their limited information about buildings' life-span via simply television and internet. Their understanding about energy-saving buildings remain shallow and simple with no strong sense of approval and awareness. They don't have any intuitionistic experience and feeling about the upcoming energy-saving buildings transform or new-built ones. For the concerns mentioned above, government and media shall increase the promotion of energy-saving buildings, thereby realizing the dream of low-carbon lifestyle. 
2.As it's found out in this research, average life-span of the existing buildings is about 31 years, differences between categories are obvious. Existing and removed buildings' life-span still have a far cry from our country's building designing regulations, which basically proves the point that our country's buildings' life-span is too short.

3.Internal factors affect a building's life-span, but not mostly. Statistics shows that the utilization of a building, in some way affect its life-span. The constructing type, number of story has nothing to do with its life-span. Such external factors as economic interest, government's achievement steering, urban function updating are the main factors that lead to the short buildings' life-span. That's why to extend a building's life-span, sustainable development of both economy and society in the building's located area is required.

\section{Suggestions:}

1.Create a better law system and build up a buildings' life-span evaluation system. Government and institution should build up a buildings' life-span evaluation system and set the standard of building-removing loud and clear. Additionally, series of policy, laws and regulation is required, a building-removing procedure and a verifying and supervising system should be completed, thus making removing and rebuilding a structure more transparent.

2.Establish the concept of urban sustainable development. Extending the life-span of buildings is an important way to save energy, as well as an effective means of accomplishing China's urban sustainable development. To promote and popularize the whole-lifespan-circle, designing and building technology to make buildings' life-span and its cycle cost efficiency is an important indicator when a building is evaluated.

3.Enhance the maintenance and functional transforming technology of old buildings. Old buildings should be maintained and fixed more often, and its internal lesion should be taken cared of. Old buildings can be reused through functional transform. Old town can be a good foundation structure of a new town so as to increase the level of utilization rate of resources to eventually extend the buildings' life-span.

\section{References}

[1] O'Connor J. 2004. Survey on actual service lives for north American buildings. Woodframe Housing Durability and disaster Isues Conference, Las Vegas:1-9.

[2] You Sheng Zhang.2002. Building life cycle assessment of carbon dioxide reduction. Taiwan: National Cheng Kung University:93-113.

[3] Jian Hong Niu.2004.Urban housing, can not afford the life of "short". China Construction News: 22 October.

[4] Guiwen LIU.2012.A study on the life-span of Demolished Buildings: Based on the Investigation of Demolished Buildings in Chongqing. Research on the development of city:19(10):109-112.

[5] Mengli Zhang.2013. Analysis of the factors affecting the construction of shortening life expectancy in city renewal. The problem of city:10:2-7.

[6] KeXi Xu.2014.Location Factors Influencing the life-span of Building. Research on the development of city:21(4):119-124.

[7] Ou Yang JianTao.2008.Study on Housing Service life in City. Science and technology progress and policy:25(10):32-35.

[8] Jianjun Chen.2012.Probe into our city housing useful life. Xi'an University Of Architecture And Technology:4-5.

[9] Jian Chen.2007.The research of Building Life under Sustainable Development: 11-12.

[10] Ruili Li.2007.Method of Forecast to Neoteric Architecture's Remaining Life. Building structure:37(3):66-67. 